This work was supported by an NIH grant (to D.C.R.) and in part by grants from NIH (to P.A.K.) and Sigma Xi (to E.D.G. and J.A.T.). We gratefully acknowledge the use of the Computer Graphics Facilities at the University of California at San Francisco (R. Langridge, director and T. Ferrin, manager) and the University of North Carolina at Chapel Hill (F. Brooks, director).

Received 7 June; accepted 31 August 1983.

1. Dean, P. M. Br. J. Pharmac. 74, 39-46 (1981).

2. Hol, W. G. J., Halie, L. M. \& Sander, C. Nature 294, 532-536 (1981).

3. Sheridan, R. P., Levy, R. M. \& Salemme, F. R. Proc natm Acad Sci U.S. A. 79, 4545-4549 (1982).

4. Perutz, M. F. Science 201, 1187-1191 (1978)

5. Hayes, D. M. \& Kollman, P. A. J. Am. chem. Soc. 98, 7811-7816 (1976)

6. Sheridan, R. P. \& Allen, L. C. J. Am. chem. Soc. 103, 1544-1550 (1981)

7. Warshel, A. \& Levitt, M. J. molec. Biol. 103, 227-249 (1976).

8. Blaney, J. M. et al. J. Am. chem Soc. 104, 6424-6434 (1982).
9. Weiner, P. K., Langridge, R., Blaney, J. M., Schaefer, R. \& Kollman, P. A. Proc. natn. Acad. Sci. U.S A 79, 3754-3758 (1982).

10. Pullman, B., Lavery, R. \& Pullman, A. Eur. J. Biochem. 124, 229-238 (1982).

11. Friend, S. H., March, K. L., Hanania, G. I. H. \& Gurd, F. R. N. Biochemistry 19, 3039-3047 (1980)

12. Salin, M. L. \& Wilson, W. W. Molec, cell. Biochem. 36, 157-161 (1981)

13. Cudd, A. \& Fridovich, I. J. biol. Chem. 257, 11443-11447 (1982).

14. Koppenol, W. H. in Oxygen and Oxy-Radicals in Chemistry and Biology (eds Powers, E. L. \& Rodgers, M. A. J.) 671-676 (Academic, New York, 1981).

15. Malinowski, D. P. \& Fridovich, I. Biochemistry 18, 5905-5917 (1979)

16. Tainer, J. A., Getzoff, E. D., Richardson, J. S. \& Richardson, D. C. Nature (this issue).

17. Klug, D., Rabani, J. \& Fridovich, I. J. biol. Chem. 247, 4839-4842 (1972).

18. Margerum, D. W., Cayley, G. R., Weatherburn, D. C. \& Pagenkopf, G. K. in Coordination Chemistry Vol. 2 (ed. Martell, A. E.) 1-220 (American Chemical Society, Washington DC, 1978).

19. Hopfinger, A. J. in Conformational Propenties of Macromolecules (eds Horecker, B., Kaplan. N. O. Marmur, J. \& Scheraga, H. A.) 39 (Academic, New York, 1973).

20. Gelin, B. R. \& Karplus, M. Biochemistry 18, 1256-1268 (1979).

21. Dearing, A., Weiner, P. \& Kollman, P. A. Nucleic Acids Res. 9, 1483-1497 (1981).

22. Connolly, M. L. Science 221, 709-713 (1983).

23. Weiner, P. K. \& Kollman, P. A. J. comp. Chem. 2, 287-303 (1981)

24. Adams, D. J. Chem. phys. Lett. 62, 329-333 (1979).

25. O'Donnell, T. J. \& Olson, A. J. Computer Graphics 15, 133-142 (1981).

\section{Expression of Klebsiella nitrogen fixation genes in Azotobacter-a caution}

\section{Frank Cannon}

BioTechnical International, Inc., 85 Bolton Street, Cambridge, Massachusetts 02140, USA

\section{John Postgate}

ARC Unit of Nitrogen Fixation, University of Sussex, Brighton BN1 9RQ, UK

IN 1976 we reported in this journal ${ }^{1}$ the correction of structural nif mutations of Azotobacter vinelandii (strains UW1, 10, 100 and 38 ) by a plasmid RP41 (now called pRD1) which carries the nif cluster of Klebsiella pneumoniae.

We are now obliged to report that we cannot repeat this effect. The original Nif $^{+}$transconjugant $A z$ otobacter strains were lost and in several attempts to obtain new ones we have used both pRD1 and a derivative, pMF250, which is sometimes more stable in intergeneric transfers. Transconjugants have readily been obtained which retain nif according to transfer of the plasmid back to Escherichia coli but none shows a $\mathrm{Nif}^{+}$ phenotype either in growth or acetylene reduction tests, performed in a variety of test conditions.

We have re-examined our paper and our experimental records and are at a loss to explain this discrepancy. Our original controls, which included reversion to the Nif ${ }^{-}$phenotype on eliminating the plasmid and also immunospecific recognition of the peptides of the Klebsiella molybdoprotein in the corrected azotobacters, seem to eliminate trivial explanations, such as reversion of the nif mutants or inadequate separation of donor and recipient organisms. A substantial number of successful transconjugations were performed and human error is therefore unlikely. We are compelled to conclude either that some systematic error, which still eludes us, occurred in our early experiments or that a special nutritional or other condition, favouring nif expression, existed fortuitously which we have not been able to reproduce.

We must therefore inform your readers that our evidence for correction of structural nif mutations in $A$. vinelandii by Klebsiella nif is subject to reasonable doubt. We much regret that our publication will have misled others as much as ourselves. The recent evidence for function of Klebsiella nif $A$ in $A$. vinelandii ${ }^{2}$ is, of course, unaffected by these considerations and remains valid.

1. Cannon, F. \& Postgate, J. Nature 260, 271-272 (1976).

2. Kennedy, C. \& Robson, R. L. Nature 301, 626-628 (1983). 